\title{
FUNCTIONAL ABILITIES OF THE SCHOOL CHILDREN IN KOSOVO AND METOHIJA
}

\author{
Nevenka Zrnzević, Vuko Lakušić \\ University of Prishtina, Teacher Education Faculty-Prizren, Leposavić, Serbia
}

\begin{abstract}
The younger school age is one of the most important periods in the growth and development of a child, during which it is necessary to pay great attention to the development of the child's functional abilities. The results of recent research, especially children of younger school age, indicate that there is a problem of a constant decline in the functional abilities in pupils of both sexes. This research was conducted on a sample of 139 second grade elementary school schoolboys and schoolgirls. Four variables were examined for which is considered to give a picture of the functional status of the students: heart rate at rest (FPUMI), heart rate after load (FPPOP), Harvard step test (FHAST), and vital lung capacity in $\mathrm{cm} 3$ (FVKAP). The main goal it was to determine whether there are differences in functional abilities between schoolboys and schoolgirls of the second grade of elementary school. The results of the multivariate analysis (MANOVA) have shown that there is a statistically significant difference between the schoolboys and schoolgirls in analysed functional abilities. A univariate analysis (ANOVA) revealed that schoolboys had better results in measurements of heart rate at rest (FPUMI) and heart rate after load (FPPOP). On the Harvard step test (FHAST) and vital lung capacity measurements (FVKAP) there were no significant differences between the schoolboys and schoolgirls. It was concluded that the current physical education curriculum does not contribute sufficiently to the development of the functional abilities of the schoolboys and schoolgirls of the junior school age.
\end{abstract}

Key words: FUNCTIONAL ABILITIES/ PULS / HARVARD STEP-TEST / PHYSICAL EXERCISE / YOUNGER SCHOOL AGE.

\section{INTRODUCTION}

Under functional abilities that are of importance for person's physical activity, in physiological terms, aerobic and anaerobic abilities are included. They are very complex and depend on a number of factors, above all on the vegetative and endocrine system (Malacko \& Popovic, 2001). There is no functional ability of the cardiovascular system common to all life situations, but a series of specific abilities for different activities and situations (Malacko \& Rađo, 2004). Knowing the functioning of certain organs and systems under the influence of physical exercise is very important, especially in terms of dosage of the load which is usually done intuitively without knowing the essence of its impact on the body.

Sometimes a capable child was a child with good motor skills crucial to a certain sport. Nowadays a capable child is the one that possess a good „physi- cal fitness" which means optimal functioning of all physiological systems of the organism, and especially of the cardiovascular, respiratory and skeletal muscle systems (Committee on Sports Medicine, 1987).

Cardiovascular diseases are not so characteristic in the childhood, but research suggests that children who are physically less active are prone to cardiovascular disease (Armstrong et al. 1991; Wedderkopp et al., 2003). The World Health Organization (WHO) has proclaimed hypokinesis for risk factor number one, when it comes to human health, and points out that children and adolescents are particularly vulnerable. Serbia is one of the countries that cannot boast the health of its population, considering the fact that is in the first place in Europe in the cardiovascular system diseases. It is especially worrying that the health threat begins in childhood (Djokic et al., 
2011). In Serbia, about $67.7 \%$ of the adult population is physically inactive (National Health Survey Serbia, 2006).

By performing moderate physical activity of 30 minutes one can produce positive health effects. Activities in school settings should be performed exclusively in aerobic conditions (Janssen \& Le Blanc, 2010). Aerobic endurance represents the whole body's ability to maintain long-lasting physical activity and involve relatively large muscle groups. It is associated with the ability of the cardiovascular and respiratory system to maintain the delivery of oxygen to the engaged muscles during long-term physical activity (Radovanovic et al., 2009). For the development of aerobic capacity, fast and slow running in the nature should be used, running long sections with a moderate intensity of $60-70 \%$ in the heart rate zone (150160 beats per minute) (Brown et al., 2000; Malacko \& Rađa, 2004). Physical exercise in aerobic conditions positively influences the condition of the cardiovascular system, maintains a smooth muscularity of blood vessels, helps blood circulation, increases blood flow to all organs (Livengood et al., 1993). This contributes to the faster process of the exchange of matter and energy, deepens breathing, strengthens the breathing muscles, increases the vital capacity of the lungs. It can be said that physical exercise improves the overall psycho-physical condition and health of the organism (Viskic-Štalec et al., 2012; Kuna et al., 2012). It is a recommendation that children and young people should apply a physical activity that will last 90 minutes per day in aerobic conditions (Colley et al., 2011). Improving cardiorespiratory endurance can also be achieved by long-lasting swimming, steady running, cycling, dancing, fast walking (Committee on Sports Medicine, 1987). If a child develops a positive attitude towards physical exercise during a younger school age and masters certain motor skills, this will help him to overcome the tasks that he or she anticipates at later stages of overall life and sports development. Physical exercise at all times should be a challenge for the schoolchild. The teacher has an obligaion to constantly emphasize the importance and value of physical exercises, to create a habit among students to take care of their own body and improve their abilities, so that physical exercise becomes their everyday need.

A relatively small number of national studies and published papers relate to the functional abilities of the younger school age children. However, the status and trend of functional abilities of students was the subject of sporadic research of a different methodological and cognitive framework (Stojanovic, 1977; Zrnzevic, 1984; Krsmanovic, 1985; Đuraškovic, 2002; Kragujevic \& Rakic, I., 2004; Zrnzevic, 2007; Milanovic, 2007; Radovanovic et al., 2009). The authors who deal with the problem of physical education curriculum in the younger school age state that teaching in this age period is one of the weakest links of a complex process of physical education teaching. They state that physical education curriculum does not cause significant changes in any segment of the anthropological status of children nor it positively affect the increase in functional and motor skills (Krsmanovic, B., 1985; Milanovic, 2007; Zrnzevic et al, 2013) even though this period of pre-school and younger school age is suitable for the development of functional abilities, especially for the cardiovascular and respiratory system (Zrnzevic, 2007; "î̂É̈̈ = et al., 2008). Insufficiently developed functional abilities cannot be attributed only by genetic factors, despite the fact that there is a certain inherent basis. They can be described as insufficient physical activity and irregular exercise. The influence on their development can be a significant factor in the overall development of the individual, especially when exercising begins in pre-school age (Sabo, 2004). In order to increase the functional capacity, the exercise must be done according to the principle of overload (De Vries, 1976). If there is no such overload (when the load exceeds the threshold value) there is no improvement in endurance as an important motor or functional capability (De Vries, 1976).

Bearing in mind that $97 \%$ of children attend elementary school and have regular classes of physical education, the obligation of the school as an important social institution is to promote physical activity and its regular application. Work on increasing functional abilities also represents educational work as it leads to the attainment of willing qualities: self-control, perseverance, persistence, responsibility, discipline, consistency, etc. (Zrnzevic, 2016), and acquired habits help students in their everyday life and work. Class teachers and physical education teachers play a vital role in the realization of the goals of physical education curriculum, and their education and professional competence should be a guarantee that using modern methods will adjust the process of teaching to students' interests.

The subject of research in this paper are functional abilities of the second-grade elementary schoolboys 
and schoolgirls. The main goal it was to determine the existing measures and to conclude whether there are differences in functional abilities between schoolboys and schoolgirls of the second grade of elementary school, as well as what are the functional capacities of the analyzed school age students, in both genders, in the territory of Kosovo and Metohija and SouthEast Serbia.

\section{METHOD}

\section{Subject sample}

Functional abilities measurement was conducted on a random sample of 139 second-grade elementary schoolboys and schoolgirls from Zvecan, Leposavic and Raska (Republic of Serbia). The measurement was carried out in June 2016, in the presence of class teachers, with healthy schoolboys and schoolgirls who were implementing regular physical education curricula. Schools that participated in this non-experimental observation were located at a relatively short distance, while the teaching of physical education at the younger school age took place under the guidance of class teachers.

In line with the ethical principles of research, school directors and parents have agreed that measurements of functional abilities of students can be carried out within regular school teaching at classes of physical education.

\section{Variable sample}

For monitoring and evaluation of the response of individual organic systems to physical load during physical education, the most appropriate are the registration of changes in the cardiovascular system. The reactions of these systems in school conditions are monitored based on the heart rate variation in rest before starting the activity, during and after physical loading. Vital lung capacity value is one of the measures that can be used to estimate the state of functional abilities of students.

The following parameters were used to evaluate the function of the cardiovascular system and the general functional ability of the schoolchildren:

- FPUMI - heart rate at rest, beat $/ \mathrm{min}$. It was measured using a stethoscope placed on the chest of schoolchildren in the projection of the top of the heart.

- FPPOP - heart rate after load, beat $/ \mathrm{min}$. It was measured using a stethoscope placed on the chest of schoolchildren in the projection of the top of the heart, after administered Harvard step test.

- FHAST - Harvard step-test for assessing the adaptability of the cardiovascular and respiratory system to the physical efforts in index points. The test is performed by alternating climbing and descending from the bench with a height of $30 \mathrm{~cm}$. The Harvard step test is one of the oldest and therefore has the most modifications. Tests based on evaluating changes after the end of the effort are acceptable in massive tests carried out under more difficult conditions, because the measurement are easy, the instruments are simple, do not require expensive equipment and special conditions. In this evaluation, there was no physical activity before conducting the test. After five minutes of climbing and descending to the bench, the subject immediately sits on a chair to measure the „pulse after load”. The pulse is measured with a stethoscope, listening in the heart region (top of the heart) for one minute. The task was completed after the measured pulse and the entry of the result in the measuring sheet. To register the time required for the implementation of the modified Harvard step test, a digital standard time counter was used. After the five-minute performance of the test based on the obtained pulse values, the index, i.e. the functional ability of the subjects according to the formula, is calculated (Table 1). 
Table 1. Assessment of functional ability $\mathrm{I}_{\mathrm{w}}$ [Mazur \& Woynarowska (2003)].

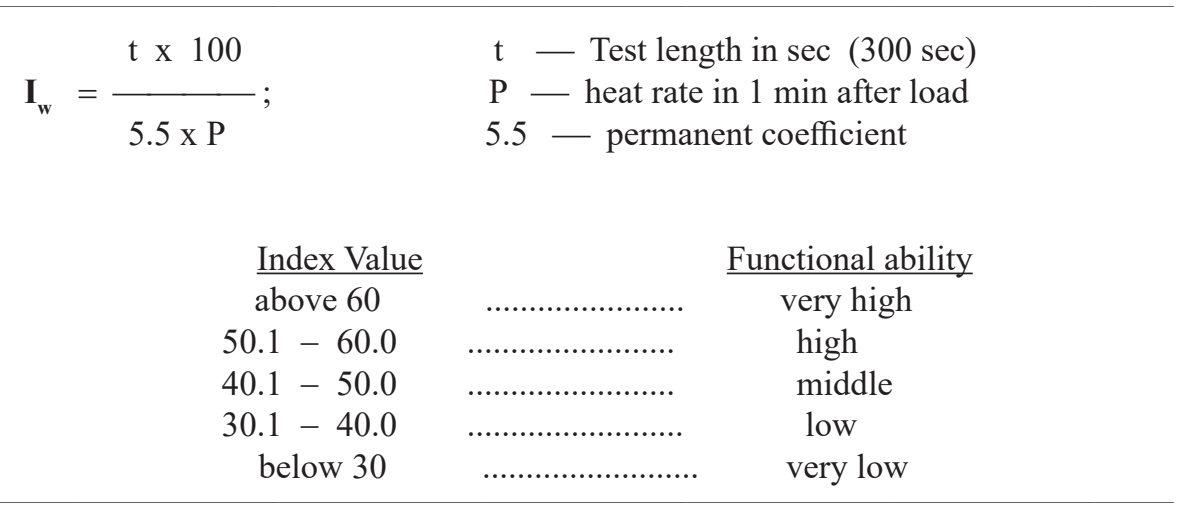

In addition to the measures of reaction of the cardiovascular system, the vital capacity of the lung was also measured (spyrometer used to measure vital lung capacity up to $7500 \mathrm{~cm}^{3}$ ). Measurement of vital lung capacity is of an invaluable value and represents a screening for the general health of the respiratory system, in the same way as blood pressure provides general information on the condition of the cardiovascular system (Miller et al., 2005). Vital capacity represents the amount of air that can be pulled out of the lungs after full inhalation. Its value depends on the general physical development of the child and with the growth and development it constantly increases. The lung volume and capacity increase until physical maturity is reached (Stojanovic, 1977).

\section{Data processing}

In this reasearch of non-experimental observation of the transfersal type, the measured values were statistically processed and analyzed through descriptive statistics and the determination of differences - analysis of variance.

\section{RESULTS WITH DISCUSSION}

Tests used in assessing the functional abilities of children should engage large muscle groups; the ef- fort must be measurable and repeatable. Testing conditions should be comparable and reproducible, children must have a good test and their health must not be exposed to danger. They can only be applied in healthy individuals who are able to attend physical education classes (Djuraskovic, 2002).

When performing functional tests, it is necessary as a functional unit, at the same time to monitor the function of cardiovascular and respiratory system. The respiratory system in healthy subjects does not represent a limitation factor during physical load, because it has large reserves and is rarely exhausted to the end (Wasserman et al., 1999).

Based on the results obtained from this non-experimental observation it can be concluded that there is a statistically significant difference in the functional abilities at the multivariate level $(\mathrm{P}=0.002)$ among the schoolboys and schoolgirls of the second grade. A statistically significant difference at the univariate level for the benefit of schoolboys, was recorded in the variables: heart rate at rest (FPUMI) $(\mathrm{p}=.012)$ and heart rate after load (FPPOP) $(\mathrm{p}=.040)$. Statistically significant difference was not found in the variables for estimation of adaptation of the cardiovascular and respiratory system to the physical effort using modified Harvard step test (FHAST) $(\mathrm{p}=.055)$ and vital lung capacity (FVKAP) $(\mathrm{p}=.330)$ (Table 2 and Table 3). 
Table 2. Basic descriptive indicators of functional abilities of teh the second grade students

\begin{tabular}{rlrrrrrrr}
\hline Sex & Variable & Min & Max & M & SD & Skew & Kurt & KS-p \\
& FVKAP & 1300 & 1800 & 1492.75 & 140.711 & .426 &,- 591 &, 014 \\
\multirow{5}{*}{ Schoolboys } & FPUMI & 84 & 102 & 92.42 & 3.615 & .112 &,- 591 &, 033 \\
& FPPOP & 108 & 148 & 123.19 & 8.940 & .198 &,- 273 &, 629 \\
& FHAST & 29.48 & 50.51 & 44.4104 & 3.57257 & -.791 & 3,108 &, 441 \\
& FVKAP & 1100 & 1900 & 1465.71 & 182.483 & .027 &,- 337 &, 343 \\
& FPUMI & 88 & 104 & 94.19 & 4.489 & .553 &,- 433 &, 007 \\
\multirow{5}{*}{ Schoolgirls } & FPPOP & 112 & 138 & 125.93 & 6.475 & -.168 &,- 577 &, 478 \\
& FHAST & 39.53 & 48.70 & 43.4289 & 2.26348 & .379 &,- 483 &, 337 \\
\hline
\end{tabular}

Legend: MIN - the minimum recorded measurement result; MAX - the maximum recorded measurement result; M - arithmetic mean; SD - standard deviation; Skew -skewness of distribution of results); Kurt - kurtosis (elongation of distribution of results); KS-p - Significance of Kolmogorov-Smyrnov test

Table 3. Differences in functional abilities in schoolboys and schoolgirls

\begin{tabular}{llrrrr} 
Variable & Group & \multicolumn{1}{c}{ M } & \multicolumn{1}{c}{ SD } & f & p \\
FVKAP & Schoolboys & 1492.75 & 140.711 & & \\
& Schoolgirls & 1465.71 & 182.483 & .955 & .330 \\
FPUMI & Schoolboys & 92.42 & 3.615 & & \\
& Schoolgirls & 94.19 & 4.489 & 6.509 & .012 \\
FPPOP & Schoolboys & 123.19 & 8.940 & & \\
& Schoolgirls & 125.93 & 6.475 & & .040 \\
FHAST & Schoolboys & 44.4104 & 3.57257 & & \\
& Schoolgirls & 43.4289 & 2.26348 & & .055 \\
& & & & &
\end{tabular}

Legend: $\mathrm{M}$ - arithmetic mean; $\mathrm{SD}$ - standard deviation; $\mathrm{f}$ - the value of the univariate $\mathrm{f}$-test; $\mathrm{p}$ - level of statistical significance of univariate f-test; F-value of Wilks F-test; P - level of statistical significance of Wilks F-test;

This research has shown that schoolboys and schoolgirls in Kosovo and Metohija and from the south of Serbia have lower values of vital lung capacity (FVKAP) compared to the values obtained in previous studies (Stojanovic, 1977; Krsmanovic, 1985; Kragujevic \& Rakic, 2004; Zrnzevic et al., 2013). The children of the younger school age have shallow, superficial and accelerated respiration, which at rest amounts to about 22 to 23 inhales, or exhales per minute. With an adult, this is considerably less and amounts to about 15 to 16 inhales or exhales per min- ute. Because of the relatively weak muscle that participates in the breathing process, the vital capacity in the period of the younger school age, at the beginning is about $1450 \mathrm{~cm}^{3}$ for boys and $1400 \mathrm{~cm}^{3}$ for girls and by the end of this age period it is about $2250 \mathrm{~cm}^{3}$ for boys and about $2100 \mathrm{~cm}^{3}$ for girls (Kragujevic \& Rakic, 2004).

Persons who are training have a lower respiratory minute volume at the same load, higher blood circulation in the lungs, higher strength and endurance of the respiratory muscles as compared to the non- 
training ones (Jakovljevic et al. 2012). Significant increase in vital capacity is possible due to the increased physical activity, and in order to estimate the intensity of the load, we can use heart rate values: heart rate values of 130 to 150 beats (low-intensity work); from 150 to 170 beats (medium-intensity work); from 170 to 180 beats (sub maximal intensity); over 190 beats per minute (work of maximum intensity) (Kragujevic, 1985).

It is difficult to determine the heart rate at rest, because the condition of the physical stress of the organism and the emotional state are difficult to maintain under control. Lower heart rates at rest provide a greater possibility of adjusting to increased body strains. So far, research has shown that in the trained individuals there is a decrease in the value of the heart rate at rest and the value of the heart rate after loading (Okicic, 2003; Radovanovic et al., 2009; Zrnzevic et al., 2013); The values of the heart rate at rest and after the load are higher than the values obtained on the same population in previous research, which is considered a negative phenomenon (Djuraskovic, 2002; Kragujevic \& Rakic, 2004; Zrnzevic et al., 2013).

The Harvard Step Test measurement results (FHAST), which was used us to estimate physical fitness for physical effort, indicated a low level of functional abilities of the schoolboys and schoolgirls. The average value of the index of adaptation of the cardiovascular and respiratory system to physical effort (FHAST) is 44.41 for schoolboy and 43.42 index points for schoolgirls, which is closer to the limit between medium and low functional abilities (Table 2). The obtained values are lower in comparison to the previous research (Djuraskovic, 2002; Kragujevic \& Rakic, 2004; Zrnzevic et al., 2013).

Children of the younger school age should be allowed to perform daily physical exercise, they should be recommended to perform activities through athletics, gymnastics and swimming, because they are the activities that are exerting most effective impact on the psychosomatic status of children (Georgiev et al., 2009). Schools need to engage children more through various activities, and parents should be encouraged to practice with children as well. It is important that all family members are involved, so that physical activity becomes an integral part of the lifestyle of each family (Rowland \& Boyajian, 1995). Proper planning, programming, and dosage of physi- cal load can influence changes in the parameters for the assessment of cardiorespiratory abilities. The exercise intensity should be at least $50 \%$ of the maximum heart rate in order to lead to positive changes and satisfactory results.

\section{CONCLUSION}

Systematic exercise and optimal physical load lead to significant positive changes in the development of the cardiovascular and respiratory system. There is an increase in vital capacity, a decrease in the heart rate at rest and after the exercise, the functions of these organs gradually adapt to effort, which contributes to the economy of their work.

Measurements and analysis of the obtained parameters in this paper have shown that there is a statistically significant difference between the schoolboys and schoolgirls of the second grade in selected functional abilities. Statistically significant difference was not found in the index of adaptation of the cardiovascular and respiratory system to the physical effort and vital lung capacity.

The functional abilities of the schoolboys and schoolgirls are at a lower level as compared to the previous research.

Systematic physical exercise can greatly influence the proper development and the elimination of the negative impact of modern lifestyles. The right choice of exercises, optimal intensity and the length of their duration is an important prerequisite to ensure the proper development of organism and organ systems. The most suitable activities for the development of the functional skills in the younger school age are: swimming, cycling, steady running, sports games, elementary games with running, rope skipping, and polygons.

Physical education teachers can use the results of this observation to assess the status and flow of students' adaptation to the existing physical education program, but also to question whether the program contents are in accordance with the needs of students.

Following the aim of this observation it can be concluded that teachers in the teaching process need to dedicate a special attention to the development of functional abilities of school age students. Physical 
education curriculum needs more important programs and material support, as well as more active

\section{REFERENCES}

1. Armstrong, N., Williams, J., Balding, J., Gentle, P. \& Kirby, B. (1991). Cardiopulmonary fitness, physical activity patterns, and selected coronary risk factor variables in 11-to 16-year-olds. Pediatric Exercise Science, 3(3), 219-228.

2. Bigovic, M. (2003). The efficiency of physical education teaching depending on the level of professional competence of teachers. Unpublished Master's thesis. Faculty of Physical Education, Novi Sad.

3. Brown, L., Ferrigno, V. \& Santana, C. (2000). Training for speed, agility and quickness. Champaign IL: Human Kinetics.

4. Colley, R. C., Garriguet, D., Janssen, I., Craig, C. L., Clarke, J. \& Tremblay, M. S. (2011). Physical activity of Canadian children and youth: accelerometer results from the 2007 to 2009 Canadian Health Measures Survey. Health reports, 22(1), 15-23.

5. Committee on Sports Medicine. (1987). Physical Fitness and the Schools. Pediatrics, 80(3), 445450 .

6. Georgiev, G., Aleksandrovic, M. \& Petrov, L. (2009). Defining and comparison of motor structure between schoolboys and schoolgirls aged 12 . Glasnik Antropološkog društva Srbije, 44, 87-94.

7. De Vries, A. H. (1976). Physiology of physical strains in sport and physical education. Belgrade: NIP Partizan.

8. Donnelly, J. E., Blair, S. N., Jakicic, J., Manore, M. \& Rankin, J. (2009). American College of Sports Medicine Position Stand. Appropriate Physical activity intervention strategies for weight loss and prevention of weight regain for adults. Medicine and Science in Sports and Exercise, 41(2), 459-471.

9. Djokic, Z., Medjedovic, B. \& Smiljanic, J. (2011). Status of nutrition, postural status and the quality of physical education teaching in primary schools. TIMS Acta-Journal of sport sciences, tourism and wellness, 5(1), 10-19.

10. Djuraskovic, R. (2002). Sports medicine. Nis: SLIC. involvement of children in sports activities in order to stop the trend of decline in functional abilities.

11. Jakovljevic, V., Bosnjak, G., Jovanovic, S. \&Tesanovic, G. (2012). Connection between lungs vital capacity and results of running on $100 \mathrm{~m}, 400$ $\mathrm{m}$ and $800 \mathrm{~m}$. In M. Dopsaj, I. Juhas, G. Kasum (ed.), Thematic book of proceeding from the International Scientific Conference Effects of applying physical activity on the anthropological status of children, youth and adults (p.689-695). Belgrade: Faculty of Sport and Physical Education.

12. Janssen, I. \& Le Blanc, A. G. (2010). Systematic review of the health benefits of physical activity and fitness in school-aged children and youth. International Journal of Behavioral nutrition and physical activity, 7(1), 40.

13. Kragujevic, G. (1985). Methodics of physical education. Belgrade: Textbook publishing Institute.

14. Kragujevic, G. \& Rakic, I. (2004). Physical Education in the first grade of the elementary school: Manual for Teachers. Belgrade: Textbook publishing Institute.

15. Krsmanovic, B. (1985). Efficiency of physical education curriculum depending on the model of teaching (Unpublished doctoral dissertation). Faculty of Physical Education, Novi Sad.

16. Kuna, D., Cular, D. \& Dzajic, S. (2012). Effects of the application of modern aerobics in PE classes. In M. Andrijašević, D. Jurakić (ed.), Book of Proceedings from the International Scientific and Professional Conference on Educational and Health Issues of Sports and Recreation (p.150-156). Križevci: Croatia Graf.

17. Livengood, J. R., Caspersen, C. J., Koplan, J. P., Blair, S. \& Curfman, G. (1993). The health benefits of exercise author's reply. The New England journal of medicine, 328(25), 1852-1853.

18. Malacko, J. \& Popovic, D. (2001). Methodology of kinesiological - anthropological research. Leposavic: Faculty of Physical Education.

19. Malacko, J. \& Rađo, I. (2004). Technology of sport and sport training. Sarajevo: Faculty of Sports and Physical Education. 
20. Markovic, M. \& Findak, V. (1997). The devrlopment of motor and functional abilities of elementary and secondary schoolgirls. Napredak, časopis za pedagogijsku teoriju i praksu, 138(2), 160-166.

21. Mazur, J. \& Woynarowska, B. (2003). Indicators of social inequalities for school-age children health surveys. Przeglad epidemiologiczny, 58(2), 377-390.

22. Milanovic, I. (2007). Effects of programmed physical education teaching in the younger school age. Fizička kultura, 61(1-2), 43-56.

23. Miller, M. R., Hankinson, J. A. T. S., Brusasco, V., Burgos, F., Casaburi, R., Coates, A. \& Jensen, R. (2005). Standardisation of spirometry. European respiratory journal, 26 (2), 319-338.

24. National Healt Survey Serbia, (2006), Republic of Serbia: Ministry of Health. Available 23.12.2017. (17h) on http://www.batut.org.rs/download/publikacije/National\%20Health\%20Survey\%20Serbia\%202006.pdf

25. Okicic, T. (2003). The influence of sports eksperience lenght on pulse frequvency in state ofresting and in exercise at sportsmen. Facta universitatis: Series Physical Education and Sport, 1(6), 51-58.

26. Radovanovic, D., Aleksandrovic, M., Stojiljkovic, N., Ignjatovic, A., Popovic, T. \& Marinkovic, M. (2009). Influence of physical training on cardiorespiratory endurance in preadolescent age. Acta Medica Medianae, 48(1), 37-40.

27. Rowland, T. W. \& Boyajian, A. (1995). Aerobic response to endurance exercise training in children. Pediatrics, 96(4), 654-658.

28. Sabo, E. (2004). Influence of the length of stay in playschool to the development of functional capabilities of pre-school boys. Физичка култура, 57/58(1-4), 19-25.
29. Stojanovic, M. (1977). Biology of the development of man with the basics in sports medicine. Belgrade: Faculty of physical education.

30. Zrnzevic, N. (2007). Transformation of the morfological characteristics of the functional and motor abilities of the schoolchildren (Unpublished doctoral dissertation). Faculty of Sport and Physical Education, Nis.

31. Zrnzevic, N., Lilic, Lj. \& Zrnzevic, J. (2013). Contribution of the experimental physical education curricula to the functional abilities development. Research in Kinesiology, 41(1), 101-105.

32. Zrnzevic, N. (2016). Methodics of physical education. Leposavic: Teacher Education Faculty Prizren-Leposavic.

33. Žuvela, F., Maleš, B. \& Katić, R. (2008). The effects of track and fieldtraining on the motor abilities of seven-year-old boys. Kinesiologia Slovenica, 14(3), 44-49.

34. Viskić-Štalec, N., Štalec, J., Katić, R., Podrovac, Đ. \& Katović, D. (2007). The impact of dance-aerobics training on the morpho-motor status in female high-schoolers. Collegium Antropologicum, 31, 259-266.

35. Wasserman, K., Hansen, J. E. \& Sue, D. Y. (1999). Principles of exercise testing and interpretation ( ${ }^{\text {rd }}$ ed.). Philadelphia: Lippincott Williams \& Wilkins.

36. Wedderkopp, N., Froberg, K., Hansen, H. S., Riddoch, C. \& Andersen, L. B. (2003). Cardiovascular risk factors cluster in children and adolescents with low physical fitness: The European Youth Heart Study (EYHS). Pediatric Exercise Science, 15(4), 419-427. 


\title{
CAPACIDADES FUNCIONALES DE LOS ALUMNOS EN LAS ESCUELAS EN KOSOVO Y METOJIA
}

\begin{abstract}
Extracto
La edad escolar temprana representa uno de los periodos más importantes en el crecimiento y desarrollo durante el cual es necesario dedicar una gran atención al desarrollo de las capacidades funcionales del niño. Los resultados de la investigación, sobre todo de los niños de edad escolar temprana, indican que existe el problema de la caída constate de las capacidades funcionales en los alumnos de ambos sexos. La presente investigación se realizó en una muestra de 139 alumnos y alumnas del segundo grado de la primaria. Se investigaron 4 variables estimadas como las que pueden dar una imagen del estatus funcional de los alumnos, como sigue: la frecuencia del ritmo cardiaco - pulso en reposo (FCR), el pulso inmediatamente después de la carga (FIDC) en la prueba del escalón de Hardvard (FPEH) y la capacidad pulmonar vital (FCPV). El objetivo principal era establecer si existen diferencias en las capacidades funcionales entre los alumnos y las alumnas del segundo grado de la primaria. Los resultados del análisis miltivariante (MANOVA) demostraron que existe una diferencia estadísticamente importante entre los alumnos y las alumnas en las capacidades funcionales analizadas. Por el análisis univariante (ANOVA) se estableció que los alumnos tuvieron mejores indicadores en la medición del pulso en reposo (FCR) y del pulso después de la carga (FIDC). En la prueba del escalón de Harvard (FPEH) y en la medición de la capacidad pulmonar vital (FCPV) no se estableció una diferencia estadísticamente importante entre los alumnos y las alumnas. Se concluyó que el programa actual de los ejercicios físicos no contribuye en la medida suficiente al desarrollo de las capacidades funcionales de los alumnos y las alumnas de edad escolar temprana.
\end{abstract}

Palabras claves: CAPACIDADES FUNCIONALES / PRUEBA DEL ESCALÓN DE HARVARD / EJERCICIOS FÍSICOS / EDAD ESCOLAR TEMPRANA

Received: 05.09. 2018.

Accepted: 15.12.2018. 


\title{
ФУНКЦИОНАЛНЕ СПОСОБНОСТИ УЧЕНИКА У ШКОЛАМА НА КОСОВУ И МЕТОХИЈИ
}

\author{
Невенка Зрнзевић, Вуко Лакушић \\ Универзитет у Приштини, Учитељски факултет у Призрену, Лепосавић
}

\begin{abstract}
Сажетак
Млађи школски узраст представља један од најважнијих периода у развоју функционалних способности детета. Резултати истраживања, посебно деце млађег школског узраста, указују да постоји проблем константног опадања функционалних способности код ученика оба пола. Ово истраживање је спроведено на узорку од 139 ученика и ученица другог разреда основне школе. Испитиване су четири варијабле, које могу пружити слику фунцкионалног статуса ученика, и то: фреквенција срчаног рада - пулс у миру (FPUMI), пулс непосредно након оптерећења (FPPOP) на харвардском степ-тесту (FHAST) и витални капацитет плућа (FVKAP). Основни циљ је био утврдити да ли постоје разлике у функционалним способностима између ученика и ученица другог разреда основне школе. Резултати мултиваријантне анализе (MANOVA) су показали да постоји статистички значајна разлика између ученика и ученица у анализираним функционалним способностима. Униваријантном анализом (ANOVA) утврђено је да су ученици имали боље показатеље у мери пулс у миру (FPUMI) и пулс након оптерећења (FPPOP). На хардвардском степ-тесту (FHAST) и мери витални капацитет плућа (FVKAP) није утврђена статистички значајна разлика између ученика и ученица. Закључено је да актуелни програм физичког вежбања не доприноси у довољној мери развоју функционалних способности ученика и ученица млађег школског узраста.
\end{abstract}

КљУчне речи: ФУНКЦИОНАЛНЕ СПОСОБНОСТИ / ХАРВАРДСКИ СТЕП-ТЕСТ / ФИЗИЧКО ВЕЖБАҢЕ / МЛАЂИ ШКОЛСКИ УЗРАСТ.

\section{УВОД}

Под функционалним способностима од значаја за физичку активност човека, у физиолошком смислу, подразумевају се аеробне и анаеробне способности. Оне су веома комплексне и зависе од више чинилаца, а пре свега од вегетативног и ендокриног система (Малацко \& Поповић, 2001). Не постоји функционална способност кардиоваскуларног система заједничка за све животне ситуације, већ низ специфичних способности за различите активности и ситуације (Малацко \& Рађо, 2004). Познавање функционисања појединих органа и система под утицајем физичког вежбања је веома значајно, а посебно се то односи на дозирање оптерећења које се углавном врши интуитивно, без познавања суштине његовог деловања на организам.
Некада се способним дететом сматрало дете које поседује добре моторичке способности пресудне за одређени спорт. Данас се под способним дететом сматра дете које поседује добру „физичку кондицију“ која подразумева оптимално функционисање свих физиолошких система организма, а посебно кардиоваскуларног, респираторног и скелетномишићног система (Committee on Sports Medicine, 1987).

Кардиоваскуларна обољења нису толико карактеристична за дечји узраст, али истраживања указују да деца која су физички мање активна имају предиспозицију за кардиоваскуларне болести (Armstrong et al. 1991; Wedderkopp et al. 2003). Светска здравствена организација (СЗО) прогласила је хипокинезију за фактор ризика број један, када је у питању људско здравље и истиче да 
су посебно угрожена деца и адолесценти. Србија спада у земље које не могу да се похвале здрављем свог становништва, с обзиром да је по смртности од болести кардиоваскуларног система на првом месту у Европи. Посебно је забрињавајуће што здравствена угроженост почиње још у дечијем узрасту (Ђокић и сар. 2011). У Србији је око 67,7\% одраслог становништва недовољно физички ативно (National Healt Survey Serbia, 2006).

Свакодневном умереном физичком активношћу у трајању од 30 минута могу се остварити позитивни здравствени ефекти. Активности у школским условима треба изводити искључиво у аеробним условима (Janssen \& Le Blanc, 2010). Аеробна издржљивост представља способност читавог тела да одржава дуготрајну физичку активност и укључује релативно велике мишићне групе. Повезана је са функцијом кардиоваскуларног и респираторног система да одржавају допремање кисеоника до ангажованих мишића током дуготрајне физичке активности (Радовановић и сар 2009). За развој аеробног капацитета треба користити брза и спора трчања у природи, трчања дугачких деоница умереним интензитетом 60-70\%, у зони максималне фреквенције срца (150-160 откуцаја у минути) (Brown et al., 2000; Малацко \& Рађа, 2004). Физичко вежбање у аеробним условима позитивно утиче на стање кардиоваскуларног систем, одржава глатку мускулатуру крвних судова, помаже циркулацију крви, повећава количину прокрвављења свих органа (Livengood et al, 1993). То доприноси бржем процесу размене материја и енергије, продубљује се дисање, јачају дисајни мишићи, повећава се витални капацитет плућа. Може се рећи да физичко вежбање унапређује целокупно психофизичко стање и здравље организма (Вискић-Шталец и сар, 2007; Куна и сар. 2012). Препорука је да деца и млади треба да примењују физичку активност која ће трајати 90 минута дневно у аеробним условима (Colley et al, 2011). Побољшање кардиореспираторне издржљивости може бити постигнуто и дуготрајним пливањем, истрајним трчањем, вожњом бицикла, плесом, брзим ходањем (Committee on Sports Medicine, 1987). Уколико дете током млађег школског узраста створи позитиван однос према физичком вежбању и овлада одређеним моторичким вештинама, то ће му помоћи да лакше савлада задатке који га очекују у каснијим фазама укупног животног и спортског развоја. Физичко вежбање на сваком часу треба да буде изазов за ученика. Наставник је у обавези да константно наглашава важност и вредност физичких вежби, ствара навику међу ученицима да се старају о сопственом телу и побољшавају своје способности, тако да физичко вежбање постане њихова свакодневна потреба.

Релативно је мали број националних истраживања и публикованих радова који се односе на функционалне способности деце млађег школског узраста. Ипак, статус и тренд функционалних способности ученика је био предмет спорадичних истраживања различитог методолошког и сазнајног оквира (Стојановић, 1977, Зрнзевић, 1984, Крсмановић, 1985, Ђурашковић, 2002., Крагујевић \& Ракић, 2004., Зрнзевић, 2007, Милнаовић, 2007, Радовановић и сар. 2009). Аутори који су се бавили проблемом физичког васпитања у млађем школском узрасту наводе да је настава у овом узрасном периоду једна од најслабијих карика сложеног процеса физичког васпитања. Наводе да програм физичког васпитања не изазива значајне промене ни у ком сегменту антрополошког статуса деце, те да не утиче позитивно ни на пораст функционалних и моторичких способности (Крсмановић, 1985; Милановић, 2007; Зрнзевић и сар. 2013), иако је период предшколског и млађег школског узраста погодан за развој функционалних способности, а посебно кардиоваскуларног и респираторног система (Зрнзевић, 2007; Жувела и cap. 2008). Недовољно развијене функционалне способности не могу се детерминисати само генетским факторима, и поред тога што постоји одређена наследна основа. Оне се могу описати недовољном физичком активношћу и нередовним вежбањем. Утицај на њихов развој може бити значајан чинилац укупног развоја јединке, посебно када се са вежбањем почне још у предшколском узрасту (Сабо, 2004). Како би се функционалне способности повећале, вежбање мора да се одвија по принципу надоптерећења (De Vries, 1976). Ако нема таквог оптерећења (када оптерећење прелази пражне вредности) нема ни побољшања издржљивости као важне моторичке, али и функционалне способности (De Vries, 1976).

Имајући у виду да 97\% деце похађа основну школу, и има редовну наставу физичког васпитања, обавеза школе као важне друштвене 
институције је да промовише физичку активност и њено редовно одвијање. Рад на повећању функционалних способности уједно представља и васпитни рад, јер код ученика доводи до учвршћивања вољних квалитета: самосавлађивања, упорности, истрајности, одговорности, дисциплине, доследности итд. (Зрнзевић, 2016), а стечене навике помажу ученицима у свакодневном животу и раду. Учитељи разредне наставе и наставници физичког васпитања имају кључну улогу у реализацији циљева наставе физичког васпитања, а њихово образовање и професионална компетентност требало би да буду гарант да ће уз примену савремених метода прилагодити процес наставе интересима ученика.

Предмет истраживања у овом раду су функционалне способности ученика и ученица другог разреда основне школе. Основни циљ је утврдити постојеће мере и доћи до закључка да ли постоје разлике у функционалним способностима између ученика и ученица другог разреда основне школе, као и какве су функционалне способности анализираног узраста, оба пола, на простору Косова и Метохије и Југо-источне Србије.

\section{МЕТОД}

\section{Узорак испитаника}

Мерење функционалних способности спроведено је на пригодном узорку од 139 ученика и ученица другог разреда из Звечана, Лепосавића и Рашке (Република Србија). Обављено је у јуну месецу 2016. године уз присуство наставника разредне наставе, и са здравим ученицима који су обухваћени редовном наставом физичког васпитања. Школе које су учествовале у овом неексперименталном посматрању лоциране су на релативно малој удаљености, а настава физичког васпитања у млађем школском узрасту одвија се под руководством учитеља разредне наставе.

У складу са етичким начелима истраживања, директори школа и родитељи одобрили су да се мерења функционалних способности ученика могу обавити унутар редовне наставе, на часовима физичког васпитања.

\section{Узорак варијабли}

За праћење и оцењивање реаговања појединих органских система на физичко оптерећење за време наставе физичког васпитања, најпогоднија су регистровања промена кардиоваскуларног система. Реакције ових система у школским условима пратиле су се на основу варијабли пулса срчаног рада како у миру - пре отпочињања активности, тако и током и након физичког оптерећења. Једна од мера на основу које је могуће закључивати о стању фунцкионалних спосбности ученика је и вредност виталног капацитета плућа.

За процену функције кардиоваскуларног система и процену опште функционалне способности ученика примењени су следећи параметри:

FPUMI - пулс у миру (откуцај/мин). Мерен је помоћу стетоскопа постављеног на груди ученика у пројекцији врха срца.

FPPOP - пулс после оптерећења (откуцај/минут). Мерен помоћу стетоскопа постављеног на груди ученика у пројекцији врха срца, а након администраног Харвард степ-теста.

FHAST - Харвардски степ-тест за процену прилагођености кардиоваскуларног и респираторног система на физичке напоре у индексним поенима. Тест се изводи наизменичним пењањем и спуштањем са клупице висине $30 \mathrm{~cm}$. Харвардски степ-тест је један од најстаријих и због тога и има највише модификација. Тестови који се базирају на оцењивању промена после завршетка напора, прихватљиви су у масовним испитивањима која се врше у тежим условима, јер су лаки за мерење, иструменти су једноставни и не изискују скупу опрему и специјалне услове. У овом тестирању пре извођења теста није било физичке активности. После петоминутног пењања и спуштања на клупицу, испитаник одмах седа на столицу да му се измери „пулс након оптерећења“. Пулс се мери уз помоћ стетоскопа, ослушкивањем у пределу срца (срчаног врха) у трајању од једне минуте. Задатак је завршен након измереног пулса и уписивања резултата у мерну листу. За регистровање времена потребног за извођење модификованог харвардског степ-теста коришћена је дигитална штоперица стандардне израде. Након петоминутног извођења теста, на основу добијених вредности пулса, израчунава се индекс, односно оцена функционалне способности испитаника по формули (Табела 1). 
Табела 1. Оцена функционалне способности $\mathrm{I}_{\mathrm{w}}$ (Mazur \& Woynarowska, 2003).

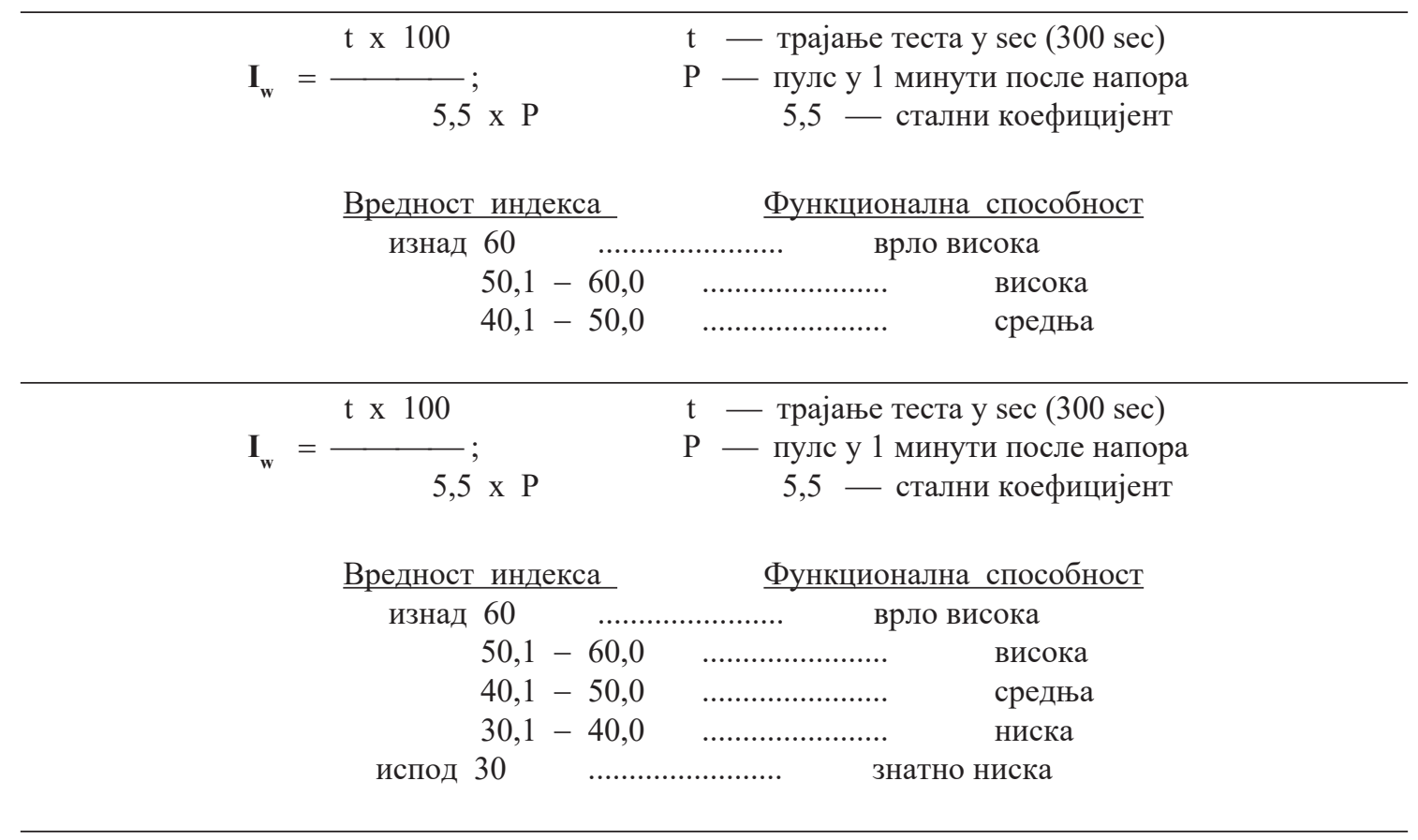

Поред мера реаговања кардиоваскуларног система, измерен је и витални капацитет плућа (коришћен је спирометар за мерење виталног капацитета плућа до $\left.7500 \mathrm{~cm}^{3}\right)$. Мерење виталног капацитета плућа је од непроцењиве вредности и представља скрининг за опште здравље респираторног система, на исти начин као што крвни притисак пружа опште информације о стању кардиоваскуларног система (Miller et al., 2005). Витални капацитет представља ону количину ваздуха која се после максималног удисаја, може пуним издисајем избацити из плућа. Његова вредност зависи од општег физичког развоја детета и са растом и развојем стално се повећава. Плућни волумен и капацитет расту све до достизања физичке зрелости (Стојановић, 1977).

\section{Обрада података}

У овом раду неексперименталног посматрања трансферзалног типа, измерене вредности су статистички обрађене и анализиране кроз дескриптивну статистику и одређивање разлика - анализу варијансе.

\section{РЕЗУЛТАТИ И ДИСКУСИЈА}

Тестови који се примењују у оцењивању функционалних способности деце треба да ангажују велике мишићне групе, напор мора да буде мерљив и да се може понављати. Услови у којима се врши тестирање треба да буду упоредиви и поновљиви, деца морају добро да подносе тест и њихово здравље не сме да се излаже опасности. Могу се примењивати само код здравих особа, способних за похађање наставе физичког васпитања (Ђурашковић, 2002).

Приликом извођења функционалних тестова, неопходно је као функционалну целину, упоредо пратити и функције кардиоваскуларног и респираторног система. Респираторни систем код здравих особа не представља фактор ограничења у току физичког оптерећења, због тога што поседује велике резерве и ретко се исцрпљује до краја (Wasserman et al,1999).

На основу добијених резултата овог неескеприменталног посматрања може се закључити да између ученика и ученица другог разреда постоји статистички значајна разлика у функционалним способностима на мултиваријантном нивоу $(\mathrm{P}=0.002)$. Статистички значајна разлика на униваријантном нивоу у корист ученика еви- 
дентирана је у варијаблама: пулс у миру (FPUMI) $(\mathrm{p}=.012)$ ипулспослеоптерећења (FРРОР) $(\mathrm{p}=.040)$. Статистички значајна разлика није евидентирана у варијаблама за процену прилагођености кар- диоваскуларног и респираторног система на физички напор - модификован харвардски стептест (FHAST) (p=.055) и витални капацитет плућа (FVKAP) (p=.330), (Табела 2 и Табела 3$)$.

Табела 2. Основни дескриптивни показатељи функционалних способности ученика другог разреда

\begin{tabular}{|c|c|c|c|c|c|c|c|c|}
\hline Pol & Varijabla & Min & $\operatorname{Max}$ & $\mathbf{M}$ & SD & Skew & Kurt & KS-p \\
\hline \multirow{5}{*}{ Дечаци } & FVKAP & 1300 & 1800 & 1492,75 & 140,711 & ,426 &,- 591 & ,014 \\
\hline & FPUMI & 84 & 102 & 92,42 & 3,615 & ,112 &,- 591 & ,033 \\
\hline & FPPOP & 108 & 148 & 123,19 & 8,940 & , 198 &,- 273 & ,629 \\
\hline & FHAST & 29,48 & 50,51 & 44,4104 & 3,57257 &,- 791 & 3,108 & ,441 \\
\hline & FVKAP & 1100 & 1900 & 1465,71 & 182,483 & ,027 &,- 337 & ,343 \\
\hline \multirow{3}{*}{ Девојчице } & FPUMI & 88 & 104 & 94,19 & 4,489 & ,553 &,- 433 & ,007 \\
\hline & FPPOP & 112 & 138 & 125,93 & 6,475 &,- 168 &,- 577 & ,478 \\
\hline & FHAST & 39,53 & 48,70 & 43,4289 & 2,26348 & 379 &,- 483 & ,337 \\
\hline
\end{tabular}

Легенда: MIN - минимални забележени резултат мерења; MAX - максимални забележени резултат мерења; M - аритметичка средина; SD - стандардна девијација; Skew - скјунис (нагнутост дистрибуције резултата); Kurt - kurtosis (издуженост дистрибуције резултата); KS-p - значајност Колмогоров-Смирнов теста.

Табела 3. Разлике у функционалним способностима дечака и девојчица

\begin{tabular}{cccccc}
\hline Varijable & Grupa & M & SD & f & p \\
\hline \multirow{2}{*}{ FVKAP } & Дечаци & 1492,75 & 140,711 & \multirow{2}{*}{, 955} &, 330 \\
& Девојчице & 1465,71 & 182,483 & & \\
\multirow{2}{*}{ FPUMI } & Дечаци & 92,42 & 3,615 & &, 012 \\
& Девојчице & 94,19 & 4,489 & 6,509 & \\
FPРОР & Дечаци & 123,19 & 8,940 & &, 040 \\
& Девојчице & 125,93 & 6,475 & & \\
FHAST & Дечаци & 44,4104 & 3,57257 & & \\
& Девојчице & 43,4289 & 2,26348 & & \\
\hline
\end{tabular}

Легенда: Група: М- аритметичка средина; SD - стандардна девијација; f - вредност униваријантног f-testa; p - ниво статистичке значајности униваријантног f-testa; F - вредност Wilksovog F-testa; P - ниво статистичке значајности Wilksovog F-testa.

Ово истраживање је показало да ученици и ученице на Косову и Метохији и са југа Србије имају ниже вредности виталног капацитета плућа (FVKAP), у односу на вредности које су добијене у ранијим истраживањима (Стојановић,
1977; Крсмановић, 1985; Крагујевић \& Ракић, 2004; Zrnzević et al., 2013). Деца млађег школског узраста имају плитко, површно и убрзано дисање, које у мировању износи око 22 до 23 удаха, односно издаха у минути. Због релативно слабе 
мускулатуре која учествује у процесу дисања, витални капацитет у периоду млађег школског узраста на почетку износи око $1450 \mathrm{~cm}^{3}$ за дечаке и $1400 \mathrm{~cm}^{3}$ за девојчице, и до краја овог узрасног периода износи око $2250 \mathrm{~cm}^{3}$ за дечаке и око $2100 \mathrm{~cm}^{3}$ за девојчице (Крагујевић \& Ракић, 2004).

Особе које тренирају имају мањи минутни волумен дисања при истом оптерећењу, већу прокрвљеност плућа, већу снагу и издржљивост дисајне мускулатуре у односу на особе које не тренирају (Јаковљевић и сар., 2012). Знатно повећање виталног капацитета могуће је услед повећане физичке активности, а како би се проценило колики је интензитет оптерећења, може се послужити пулсним вредностима: пулсне вредности од 130 до 150 откуцаја (рад малог интензитета); од 150 до 170 откуцаја (рад средњег интензитета); од 170 до 180 откуцаја (рад субмаксималног интензитета); преко 190 откуцаја у минути (рад максималног интензитета) (Крагујевић, 1985).

Пулс у миру тешко је прецизно утврдити, због тога што је стање физичког напрезања организма као и емотивно стање тешко одржати под контролом. Ниже вредности пулса у миру обезбеђују и већу могућност прилагођавања повећаним телесним напрезањима. Досадашња истраживања показала су да код особа које континуирано тренирају долази до смањења вредности пулса у миру и вредности пулса после оптерећења (Окичић, 2003; Радовановић и сар., 2009; Zrnzević et al., 2013). Вредности пулса у миру и после оптерећења веће су од вредности добијене на истој популацији у ранијим истраживањима, што се сматра негативном појавом (Ђурашковић, 2002; Крагујевић \& Ракић, 2004; Zrnzević et al., 2013).

Резултати на харвардском степ-тесту, који је коришћен за процену физичке припремљености, указали су на низак ниво функционалних способности ученика и ученица. Просечна вредност индекса прилагођености кардиоваскуларног и респираторног система на физички напор (FHAST) износила је за ученике 44,41 а за ученице 43,42 индексних поена, што је ближе граници између средње и ниске функционалне способности (табела, 2). Добијене вредности су ниже у односу на ранија, компаративна истраживања (Ђурашковић, 2002; Крагујевић, Ракић 2004; Zrnzević et al., 2013).
Деци млађег школског узраста треба омогућити свакодневно физичко вежбање, препоручити активности кроз атлетику, гимнастику и пливање, jep су то активности које најделотворније утичу на психосоматски статус деце (Georgiev, G., Aleksandrovic, M., Petrov, L., 2009). Школе треба више да ангажују децу, а кроз разне активности треба подстаћи и родитеље да вежбају са децом. Важно је да се укључе сви чланови породице, тако да физичка активност постане саставни део начина живота сваке породице (Rowland, Boyajian, 1995). Правилним планирањем, програмирањем и дозирањем оптерећења може се утицати на промене параметара за процену кардиореспираторних способности. Интензитет вежбања требало би да буде најмање $50 \%$ од максималне фрекфенције срца, како би довело до позитивних промена и задовољавајућих резултата.

\section{ЗАКЉУЧАК}

Систематско вежбање и оптимално физичко оптерећење доводе до значајних позитивних промена у развоју кардиоваскуларног и респираторног система. Долази до повећања виталног капацитета, смањења пулса у миру и после оптерећења, функције ових органа се постепено адаптирају на напор, што доприноси економичности њиховог рада.

Мерења и анализа добијених праметара у овом раду су показали да постоји статистички значајна разлика између ученика и ученица другог разреда у одабраним функционалним способностима. Статистички значајна разлика није утврђена у варијаблама прилагођености кардиоваскуларног и респираторног система на физички напор и витални капацитет плућа.

Функционалне способности ученика и ученица су на нижем нивоу у односу на претходна истраживања.

Систематским физичким вежбањем може се у великој мери утицати на правилан развој и на отклањање негативног утицаја савременог начина живота. Правилан избор вежби, оптималан интензитет и дужина њиховог трајања је важан предуслов за правилан развој организма и органских система. Најпогодније активности 
за развој функционалних способности у млађем школском узрасту су: пливање, вожња бицикла, истрајно трчање, спортске игре, елементарне игре са трчањем, прескакање вијаче, полигони.

Наставницима физичког васпитања резултати овог посматрања могу послужити за оцену стања и тока адаптација ученика на постојећи програм физичког васпитања, али и за постављање питања да ли су програмски садржаји у складу са потребама ученика.

\section{ЛИТЕРАТУРА}

1. Armstrong, N., Williams, J., Balding, J., Gentle, P., Kirby, B. (1991). Cardiopulmonary fitness, physical activity patterns, and selected coronary risk factor variables in 11-to 16-year-olds. Pediatric Exercise Science, 3(3), 219-228.

2. Bigović, M. (2003). Efikasnost nastave fizičkog vaspitanja u zavisnosti od nivoa stručne osposobljenosti nastavnika (Neobjavljeni magistarski rad). Fakultet fizičke kulture, Novi Sad.

3. Brown, L., Ferrigno, V., Santana, C. (2000). Training for speed, agility and quickness. Champaign IL: Human Kinetics.

4. Colley, R. C., Garriguet, D., Janssen, I., Craig, C. L., Clarke, J., Tremblay, M. S. (2011). Physical activity of Canadian children and youth: accelerometer results from the 2007 to 2009 Canadian Health Measures Survey. Health reports, 22(1), 15-23.

5. Committee on Sports Medicine. (1987). Physical Fitness and the Schools. Pediatrics, 80(3), 445450 .

6. Georgiev, G., Aleksandrović, M., Petrov, L. (2009). Defining and comparison of motor structure between schoolboys and schoolgirls aged 12 . Glasnik Antropološkog društva Srbije, 44, 87-94.

7. De Vries, A. H. (1976). Fiziologija fizičkih napora u sportu i fizičkom vaspitanju. Beograd: NIP Partizan.

8. Donnelly, J. E., Blair, S. N., Jakicic, J., Manore, M., Rankin, J. (2009). American College of Sports Medicine Position Stand. Appropriate Physical activity intervention strategies for weight loss and prevention of weight regain for adults. Medicine and Science in Sports and Exercise, 41(2), 459-471.
У закључку овог посматрања, наставници треба посебну пажњу да посвете развоју функционалних способности ученика и ученица. Неопходна је значајнија програмска и материјална подршка настави физичког васпитања, као и активније укључивање деце у спортске активности како би се зауставио тренд опадања функционалних способности.

9. Đokić, Z., Međedović, B., Smiljanić, J. (2011). Stanje uhranjenosti, posturalni status i kvalitet sprovođenja nastave fizičkog vaspitanja $\mathrm{u}$ osnovnim školama. TIMS Acta-Journal of sport sciences, tourism and wellness, 5(1), 10-19.

10. Đurašković, R. (2002). Sportska medicina. Niš: SLIC.

11. Jakovljević, V., Bošnjak, G., Jovanović, S., Tešanović, G. (2012). Povezanost i uticaj vitalnog kapaciteta pluća na rezultate trčanja $100 \mathrm{~m}, 400 \mathrm{~m}$ i $800 \mathrm{~m}$. U M. Dopsaj, I. Juhas, G. Kasum (ur.), Tematski zbornik radova sa Međunarodne naučne konferencije Efekti primene fizičke aktivnosti na antropološki status dece, omladine i odraslih (str.689-695). Beograd: Fakultet sporta i fizičkog vaspitanja.

12. Janssen, I., Le Blanc, A. G. (2010). Systematic review of the health benefits of physical activity and fitness in school-aged children and youth. International Journal of Behavioral nutrition and physical activity, 7(1), 40.

13. Kragujević, G. (1985). Metodika nastave fizickog vaspitanja. Beograd: Zavod za udžbenike i nastavna sredstva.

14. Kragujević, G., Rakić, I. (2004). Fizičko i $z$ dravstveno vaspitanje u prvom razredu osnovne škole: priručnik za učitelje. Beograd: Zavod za udžbenike i nastavna sredstva.

15. Krsmanović, B. (1985). Efikasnost nastave fizickog vaspitanja u zavisnosti od modela nastavnih programa (Neobjavljena doktorska disertacija). Fakultet fizičke kulture, Novi Sad.

16. Kuna, D., Čular, D., Džajić, S. (2012). Učinci primjene suvremenog aerobika u nastavi TZK. 
(Effects of the application of modern aerobics in PE classes). U M. Andrijašević, D. Jurakić (ur.), Zbornik radova sa Međunarodne znanstvenostručne konferencije Odgojni I zdravstveni aspekti sporta i rekreacije (str.150-156). Križevci: Croatia Graf.

17. Livengood, J. R., Caspersen, C. J., Koplan, J. P., Blair, S., Curfman, G. (1993). The health benefits of exercise author's reply. The New England journal of medicine, 328(25), 1852-1853.

18. Malacko, J., Popović, D. (2001). Metodologija kineziološko antropoloških istraživanja. Leposavić: Fakultet za fizičku kulturu.

19. Malacko, J., Rađo, I. (2004). Tehnologija sporta i sportskog treninga. Sarajevo: Fakultet sporta i tjelesnog odgoja.

20. Marković, M., Findak, V. (1997). Razvoj motoričkih i funkcionalnih sposobnosti učenica osnovnih i srednjih škola. Napredak, časopis za pedagogijsku teoriju i praksu, 138(2), 160-166.

21. Mazur, J., Woynarowska, B. (2003). Indicators of social inequalities for school-age children health surveys. Przeglad epidemiologiczny, 58(2), 377390.

22. Milanović, I. (2007). Efekti programirane nastave fizičkog vaspitanja u mlađem školskom uzrastu. Fizička kultura, 61(1-2), 43-56.

23. Miller, M. R., Hankinson, J. A. T. S., Brusasco, V., Burgos, F., Casaburi, R., Coates, A., Jensen, R. (2005). Standardisation of spirometry. European respiratory journal, 26 (2), 319-338.

24. National Healt Survey Serbia. (2006). Republic of Serbia: Ministry of Health. Dostupno 23.12.2017. (17h) na http://www.batut.org.rs/download/ publikacije/National $\% 20$ Health $\% 20$ Survey $\% 20$ Serbia\%202006.pdf

25. Okičić, T. (2003). The influence of sports eksperience lenght on pulse frequvency in state ofresting and in exercise at sportsmen. Facta universitatis: Series Physical Education and Sport, 1(6), 51-58.

26. Radovanović, D., Aleksandrović, M., Stojiljković, N., Ignjatović, A., Popović, T., Marinković, M. (2009). Uticaj treninga u preadolescentnom uzrastu na kardiorespiratornu izdržljivost. Acta Medica Medianae, 48(1), 37-40.

27. Rowland, T. W., Boyajian, A. (1995). Aerobic response to endurance exercise training in children. Pediatrics, 96(4), 654-658.

28. Сабо, Е. (2004). Утицај дужине боравка у дечјем вртићу на развој функционалних способности дечака предшколског узраста. Физичка култура, 57/58(1-4), 19-25.

29. Stojanović, M. (1977). Biologija razvoja čoveka sa osnovama sportske medicine. Beograd: Fakultet fizičke kulture.

30. Zrnzević, N. (2007). Transformacija morfoloških karakteristika, funkcionalnih $i$ motoričkih sposobnosti učenika (Neobjavljena doktorska disertacija). Fakultet sporta i fizičkog vaspitanja, Niš.

31. Zrnzević, N., Lilić, Lj., Zrnzević, J. (2013). Contribution of the experimental physical education curricula to the functional abilities development. Research in Kinesiology, 41(1), 101105.

32. Zrnzević, N. (2016). Metodika nastave fizičkog vaspitanja. Leposavić: Učiteljski fakultet PrizrenLeposavić.

33. Žuvela, F., Maleš, B., Katić, R. (2008). The effects of track and fieldtraining on the motor abilities of seven-year-old boys. Kinesiologia Slovenica, 14(3), 44-49.

34. Viskić-Štalec, N., Štalec, J., Katić, R., Podrovac, Đ., Katović, D. (2007). The impact of dance-aerobics training on the morpho-motor status in female high-schoolers. Collegium Antropologicum, 31, 259-266.

35. Wasserman, K., Hansen, J. E., Sue, D. Y. (1999). Principles of exercise testing and interpretation ( ${ }^{\text {rd }}$ ed.). Philadelphia: Lippincott Williams \& Wilkins.

36. Wedderkopp, N., Froberg, K., Hansen, H. S., Riddoch, C., Andersen, L. B. (2003). Cardiovascular risk factors cluster in children and adolescents with low physical fitness: The European Youth Heart Study (EYHS). Pediatric Exercise Science, 15(4), 419-427. 